\title{
ASTROINFORMATICS
}

DOI:http://dx.doi.org/10.18524/1810-4215.2019.32.181557

\section{NEW ASTROMETRIC REDUCTION OF THE SUPERCOSMOS PLATE ARCHIVE: FIRST RESULTS}

\author{
V.S. Akhmetov ${ }^{1}$, V.M. Andruk ${ }^{2}$, Yu.I. Protsyuk ${ }^{3}$, H. Relke ${ }^{4}$, I. Eglitis ${ }^{5}$ \\ ${ }^{1}$ Institute of Astronomy, V. N. Karazin Kharkiv National University, Kharkiv, \\ Ukraine,akhmetovvs@gmail.com \\ ${ }^{2}$ Main Astronomical Observatory of the National Academy of Sciences of Ukraine, \\ Kyiv, Ukraine,andruk@mao.kiev.ua \\ ${ }^{3}$ Research Institute Mykolaiv Astronomical Observatory, \\ 1 Observatorna Str., 54000 Mykolaiv, Ukraine, yuri@nao.nikolaev.ua \\ ${ }^{4}$ Walter Hohmann Observatory, Essen, Germany, helena_relke@yahoo.com \\ ${ }^{5}$ Institute of Astronomy, University of Latvia, Riga, Latvia, ilgmars.eglitis@lu.lv
}

\begin{abstract}
The arrivals of the new more accuracy reference catalogs and development of new methods and approaches for reduction astrometric data give the new life for photographic plates archives. Gaia DR2 is not only a giant step in the astrometric accuracy allowing to measure new objects it also provides plates archives observed in the past with modern accuracy. In this work we present the first results of astrometric reduction in the system of Gaia DR2 for some photographic plates that were obtained by UK Schmidt telescope (UKST) and digitized by the SuperCOSMOS scanning machine. To date the UKST has taken over 17,000 plates, the plates are stored in the Plate Library at the Royal Observatory, Edinburgh. The photographic plates are digitized to 15 bits (32768 grey levels) with a resolution of 10 microns $(0.67$ arcsec)/pixel). Each digitized Schmidt plate has size $32256 x 32256$ pixels and produces about 2 Gbyte pixel data. We are making new reduction of photographic plates that allowing to provide valuable data for future researches in astrometry as well as in astrophysics. The results of our research showed some problems for further successful implement of works started to process the digitized scans with such large size in the frame of the SuperCOSMOS program. However, the internal estimation of the accuracy position of objects are better the same results of the SuperCOSMOC reduction and will be improved after the solving these problems.
\end{abstract}

Keywords: stellar catalogs, digitized plate processing, photometry, UBV system.

АНОТАЦІЯ. Поява нових високоточних опорних каталогів, а також розробка нових методів та підходів для астрометричної редукції даних дають нове життя архіву фотографічних платівок. Gaia DR2 - це не лише гігантський крок у астрометричній точності, що дозволяє вимірювати нові об'єкти, а також дозволяє отримати та порівнювати архівні спостереження в минулому із су- часною точністю. У цій роботі ми представляємо перші результати астрометричної редукції деяких фотографічних платівок в систему опорного каталогу Gaia DR2, які були отримані Шмідт телескопом АнглоАвстралійській обсерваторії та були оцифровані за програмою сканування SuperCOSMOS. Фотографічні платівки оцифровані 15 біт (32768 рівнів сірого кольору) 3 роздільною здатністю 10 мкм на піксель, створюючи близько 2 Гбіт піксельних даних. На сьогоднішній день існує понад 17000 платівок отриманих такими Шмідт телескопами, які зберігаються в бібліотеці фотографічних платівок у Королівській обсерваторії, місто Едінбург. Ми робимо нову обробку фотографічних платівок, що дозволить отримати цінні дані для майбутніх досліджень як у галузі астрометрії. так і астрофізики. Результати наших досліджень виявили деякі складності для подальшого виконання роботи по обробці таких великих за розміром платівок програми SuperCOSMOS. Але, внутрішня оцінка точності положень об'єктів краща ніж аналогічні результати отримані SuperCOSMOS та будуть покращені після вирішення представлених проблем.

Ключові слова: зоряні каталоги, обробка оцифрованих зображень, фотометрія, система UBV.

\section{Introduction}

This work has been done to explore the possibility of extending the FON project into "deep" - from B $=17^{\mathrm{m}}$ to $\mathrm{B}=$ $22^{\mathrm{m}}$ (Pakuliak, 2016; Andruk, 2017a). In the FON project digitized scans of photographic plates with the size of $13000 \times 13000$ pixels were processed to create a catalog of positions and B-magnitude stars of the Northern Sky (Andruk, 2017b). In this paper, we examined the possibility of using our software tools (Hambly N.C. et al., 2001a) to digitized photographic plates from the Schmidt telescope at 


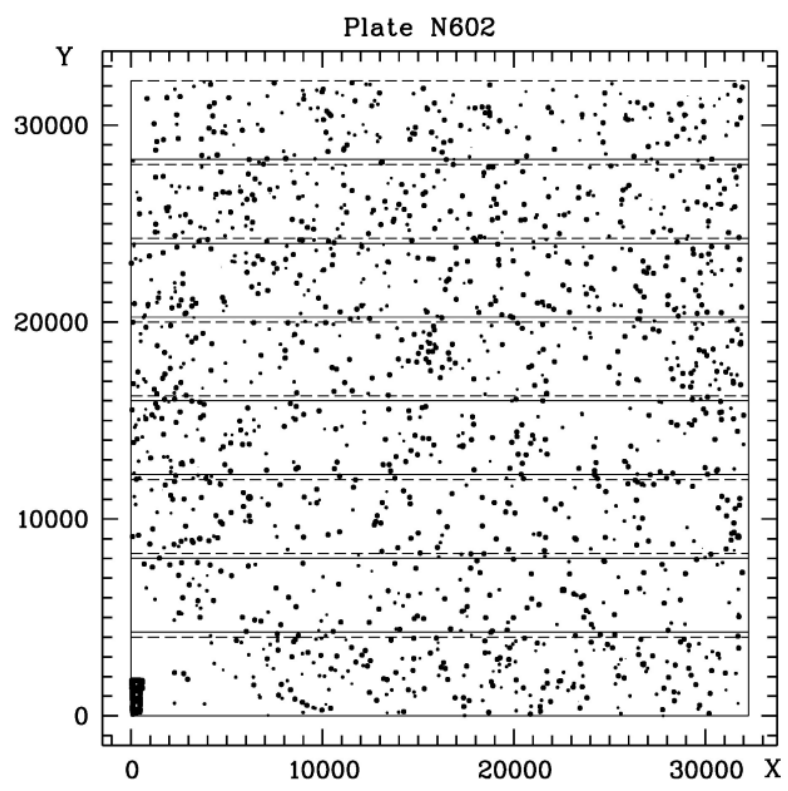

Figure 1: The 8-parts splitting scheme for the plate number 602. Only images of bright stars after the processing of the scan in the MIDAS/ROMAFOT environment are mapped.

the Anglo-Australian Observatory. This is a classic Schmidt with the following parameters: the diameter of the mirror is $1.83 \mathrm{~m}$; focal distance $-3.07 \mathrm{~m}$; a square photographic plate with the size of $356 \times 356 \mathrm{~mm}$ covers $6.4 \times 6.4$ degrees of sky; scale -67.12 arcsec/mm; spatial resolution -670 mas/pixel. To date, there are more than 17,000 photographic plates obtained by this Schmidt telescope which are stored in the Plate Library at the Royal Observatory, Edinburgh. Several plates from this Plate Library were digitized by the SuperCOSMOS scanning machine The astronegatives were digitized to 15 bits (32768 gray levels) with a spatial resolution of 10 microns per pixel. They have dimensions of 32256x32256 pixels and a volume of 2 Gbytes of pixel data (Hambly N.C. et al., 2001b). For the extracting of the star images we used the MIDAS software environment. But it has a size limit: the size of scan to be processed is no more than $20,000 \times 20,000$ pixels. The authors found an opportunity to use the Midas software environment by splitting each scan into 8 overlapped parts (bands) by the coordinates of $\mathrm{Y}$. The width of the overlapped zones is 256 pixels. As our small experience of the data processing shown, instrumental photometric values in the overlapping bands are needed for photometric alignment of all eight bands. The splitting scheme of the scan for the plate No.602 is shown on the figure 1 .

\section{The first results of the processing of plates with} the size of $32256 \times 32256$ pixels

Processing of digitized scans in the MIDAS/ROMAFOT environment allows to obtain data for all registered objects: rectangular coordinates $\mathrm{X}, \mathrm{Y}$; photometric values $\mathrm{m}$ and FWHM. The reduction of the rectangular coordinates of X,Y into the system of equatorial coordinates was carried out in the system of Tycho- 2 catalog (Hog E. et al., 2000) for stars in the range of $\mathrm{B}=9^{\mathrm{m}}-14^{\mathrm{m}}$ (Andruk, 2015; Andruk, 2016). Brighter stars were not used because of the generation of se-

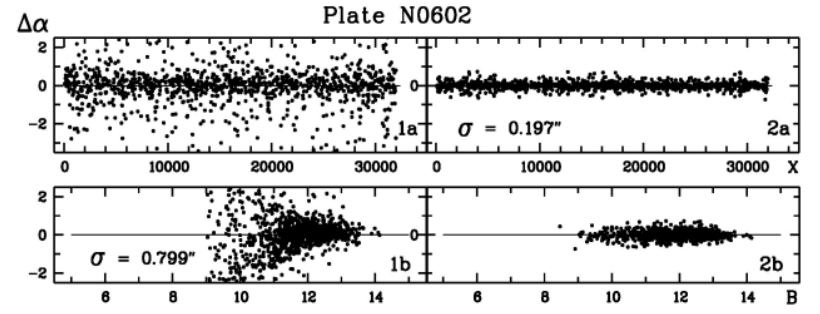

$\Delta \delta$
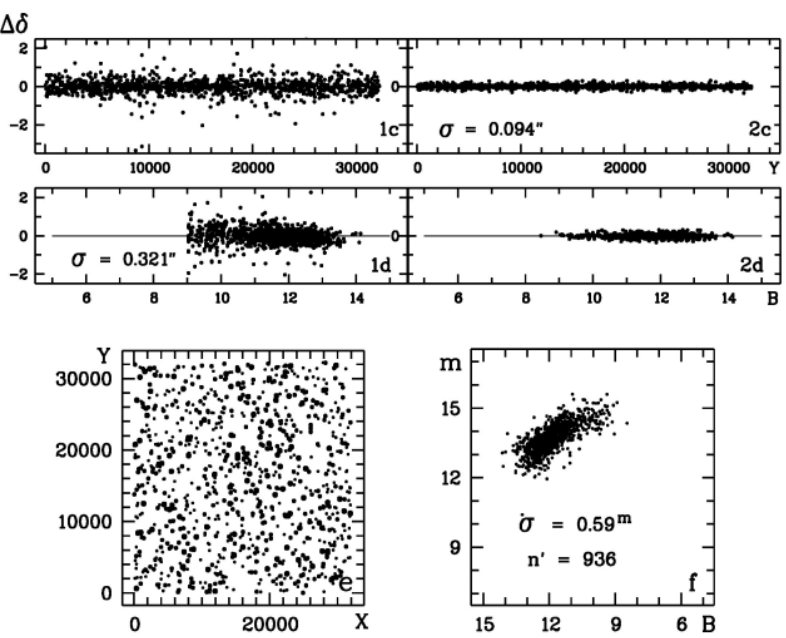

Figure 2: The distribution of errors definition of equatorial coordinates $\sigma$ (represented as differences of $\Delta \alpha, \Delta \delta$ ) in the system of Tycho- 2 catalog for the plate 602 at the initial (left panel 1a, 1b, 1c, 1d) and the final (right panel 2a, 2b, $2 c, 2 d)$ stages of reduction. Panel e is a map of the sky of bright stars. Panel f shows the plot of instrumental photometric values $\mathrm{m}$ again stellar B-values of the Tycho-2 catalog for 936 stars.

veral doubles objects instead of real one. The figure 2 shows the distribution of errors definition of equatorial coordinates $\sigma$ (represented as differences of $\Delta \alpha, \Delta \delta$ ) in the system of Tycho- 2 catalog for the plate 602 at the initial (left panel 1a, 1b, 1c, 1d) and the final (right panel 2a, 2b, $2 \mathrm{c}, 2 \mathrm{~d}$ ) stages of reduction relatively rectangle coordinates $\mathrm{X}, \mathrm{Y}$ and stellar B-values. On the bottom of the left panel (e) is a map of the sky of bright stars, on panel (f) - the plot of instrumental photometric values $m$ against stellar B-values of the Tycho- 2 catalog for 936 stars.

At this stage of the study the authors could not implement the photometric reduction of the instrumental values $\mathrm{m}$ into the B-magnitude of Johnson's system by using a characteristic curve. Due to the generation of an arbitrary number of false objects instead of real one for bright stars it was not possible to build the part of the real characteristic curve for stars brighter than $\mathrm{B}<10^{\mathrm{m}}$ in order to somehow adequately calibrate characteristic curve across the entire range of stellar values of registered objects in the system of photoelectric measurements of stars or at least in the Bsystem of Tycho-2 catalog (Relke, 2015). Therefore the authors made a photometric assessment to determine the $b_{\text {lim }}$ values of the extremely weak registered objects for several processed plates with one exposure in the B-magnitude system of the Gaia DR2 (Gaia Collaboration, 2018). Results of the photometry of the scan number 602 in the B-system of the Gaia DR2 are presented on the Figure 3. On the apanel is the plot of instrumental photometric measures $\mathrm{m}$ 


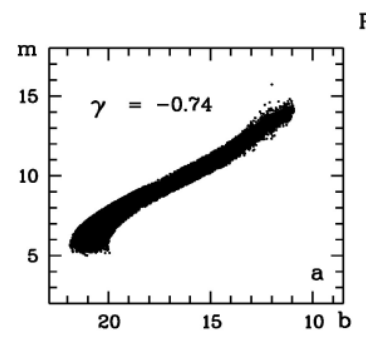

Plate 602
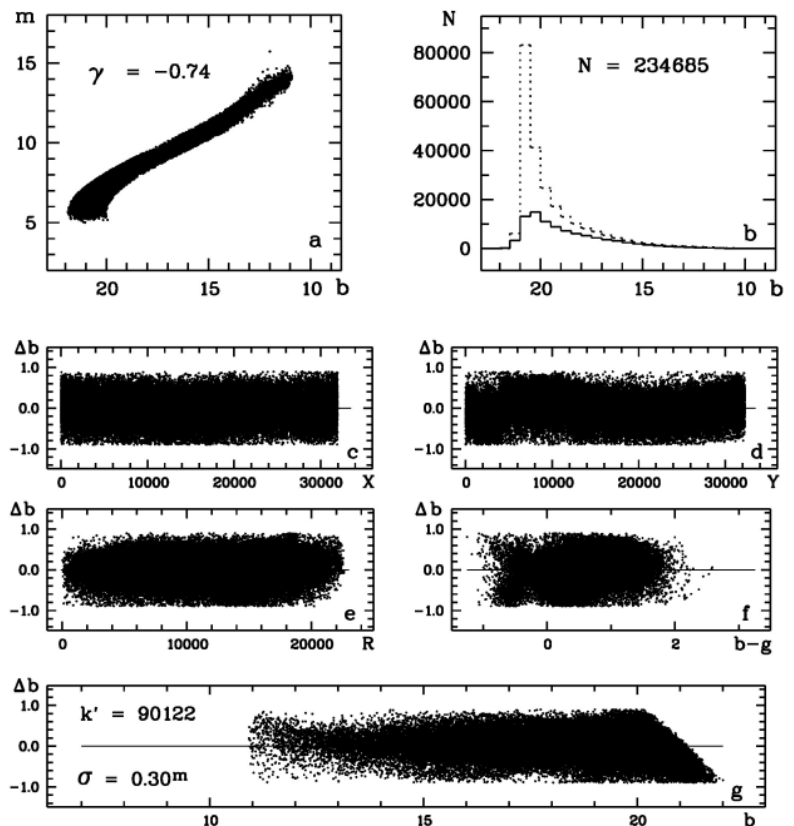

Figure 3: The results of the photometry of the scan number 602 in the B-system b of the Gaia DR2 catalog. On the a-panel is the plot of instrumental photometric measures $\mathrm{m}$ against the B-magnitudes of the Gaia DR2 catalog $(\mathrm{y}=$ -0.74 is the contrast coefficient of photo emulsion). On the b-panel - distribution of all 234685 recorded objects (points) and 90122 identified stars from the Gaia DR2 catalog (continuous line) by star intervals. On the $\mathrm{c}, \mathrm{d}, \mathrm{t}, \mathrm{f}$ and $g$ panels - the differences between the calculated $b^{\prime}$ and the catalogue $\mathrm{b}$ values $\Delta \mathrm{b}=\mathrm{b}^{\prime}-\mathrm{b}\left(\boldsymbol{\sigma}=0.30^{\mathrm{m}}\right)$ relative to the rectangular coordinates $\mathrm{X}, \mathrm{Y}$, the distance from the center of the plate $\mathrm{R}$, the $\mathrm{b}$-g color and B-magnitudes of the Gaia DR2 catalog respectively.

Table 1. Results of the processing of scans for seven plates

\begin{tabular}{|c|c|c|c|}
\hline Np/RA/DEC & Epoch & $\sigma_{\mathrm{RA}} / \sigma_{\mathrm{DE}} / \sigma_{\mathrm{B}}$ & Nobj/blim \\
\hline $\begin{array}{l}190 \\
22^{\mathrm{h}} 34^{\mathrm{m}} 54^{\mathrm{s}} \\
-54^{\circ} 47^{\prime} 20^{\prime \prime}\end{array}$ & 16.09 .79 & $\begin{array}{l}0.22^{\prime \prime} \\
0.09^{\prime \prime} \\
0.28^{m}\end{array}$ & $\begin{array}{l}267000 \\
21.3^{\mathrm{m}}\end{array}$ \\
\hline $\begin{array}{l}289 \\
22^{\mathrm{h}} 25^{\mathrm{m}} 40^{\mathrm{s}} \\
-44^{\circ} 51^{\prime} 51^{\prime \prime}\end{array}$ & 17.06 .75 & $\begin{array}{l}0.13^{\prime \prime} \\
0.07^{\prime \prime} \\
0.28^{m}\end{array}$ & $\begin{array}{l}303000 \\
21.6^{\mathrm{m}}\end{array}$ \\
\hline $\begin{array}{l}345 \\
22^{\mathrm{h}} 33^{\mathrm{m}} 29^{\mathrm{s}} \\
-39^{\circ} 51^{\prime} 16^{\prime \prime}\end{array}$ & 16.09 .77 & $\begin{array}{l}0.17^{\prime \prime} \\
0.08^{\prime \prime} \\
0.29^{m}\end{array}$ & $\begin{array}{l}296000 \\
21.5^{\mathrm{m}}\end{array}$ \\
\hline $\begin{array}{l}405 \\
22^{\mathrm{h}} 25^{\mathrm{m}} 53^{\mathrm{s}} \\
-34^{\circ} 49^{\prime} 25^{\prime \prime}\end{array}$ & 11.08 .80 & $\begin{array}{l}0.82^{\prime \prime} \\
0.18^{\prime \prime} \\
0.26^{m}\end{array}$ & $\begin{array}{l}264000 \\
21.4^{\mathrm{m}}\end{array}$ \\
\hline $\begin{array}{l}468 \\
22^{\mathrm{h}} 38^{\mathrm{m}} 50^{\mathrm{s}} \\
-29^{\circ} 50^{\prime} 49^{\prime \prime}\end{array}$ & 02.10 .80 & $\begin{array}{l}0.66^{\prime \prime} \\
0.17^{\prime \prime} \\
0.22^{m}\end{array}$ & $\begin{array}{l}204000 \\
20.1^{\mathrm{m}}\end{array}$ \\
\hline $\begin{array}{l}533 \\
22^{\mathrm{h}} 23^{\mathrm{m}} 50^{\mathrm{s}} \\
-24^{\circ} 48^{\prime} 07^{\prime \prime}\end{array}$ & 25.06 .80 & $\begin{array}{l}0.25^{\prime \prime} \\
0.11^{\prime \prime} \\
0.30^{m}\end{array}$ & $\begin{array}{l}232000 \\
21.1^{\mathrm{m}}\end{array}$ \\
\hline $\begin{array}{l}602 \\
22^{\mathrm{h} 27^{\mathrm{m}} 00^{\mathrm{s}}} \\
-19^{\circ} 47^{\prime} 00^{\prime \prime}\end{array}$ & 26.09.87 & $\begin{array}{l}0.20^{\prime \prime} \\
0.09^{\prime \prime} \\
0.30^{m}\end{array}$ & $\begin{array}{l}235000 \\
21.2^{\mathrm{m}}\end{array}$ \\
\hline
\end{tabular}

against the stellar B-values of the Gaia DR2 catalog ( $\mathrm{y}=$ -0.74 is the contrast coefficient of photo emulsion). On the b-panel - distribution of all 234685 recorded objects (points) and 90122 identified stars from the Gaia DR2 cata$\log$ (continuous line) by star intervals. On the $\mathrm{c}, \mathrm{d}, \mathrm{t}, \mathrm{f}$ and $\mathrm{g}$ panels - the differences between the calculated $b^{\prime}$ and the catalogue b values $\Delta \mathrm{b}=\mathrm{b}^{\prime}-\mathrm{b}\left(\boldsymbol{\sigma}=0.30^{\mathrm{m}}\right)$ relative to the rectangular coordinates $\mathrm{X}, \mathrm{Y}$, the distance from the center of the plate R, the b-g color and stellar B values the of the Gaia DR2 catalog respectively.

The results summary of the processing of scans for seven selected astronegatives obtained by the Schmidt Telescope of the Anglo-Australian Observatory is presented in the table 1 . The first column shows the number of plate $\mathrm{Np}$ and centers coordinates RA, DEC; the second one - observation epoch'. The reduction errors for the coordinates RA, DEC in the system of Tycho-2 catalog $\sigma_{\mathrm{RA}}, \sigma_{\mathrm{DE}}$ and the error of B-magnitudes in the B-system of Gaia DR2 catalog $\sigma_{B}$ are entered in the third column. The fourth column shows the total number of registered objects Nobj and the magnitude value for extremely weak objects in the B-system of the Gaia DR2 catalog $b_{\text {lim }}$.

\section{Conclusions}

The use of the automatic splitting of scans into several (eight) parts in the MIDAS/ROMAFOT environment allows the processing of the plates with the size of $32256 \times 32256$ pixels. However the results of our researches showed some problems that need to be solve for further successfully implement of works started to process of the digitized scans with such size in the frame of the SuperCOSMOS program.

1. In the photometric sense eight zones 4,256 pixels wide with overlapping 256 pixels at the $\mathrm{Y}$ coordinate combine not quite correctly (figure 3, d-panel). In the astrometric sense there is no such problem (figure 2, 2c-panel).

2. At the MIDAS/ROMAFOT processing stage, you need to split up the registered objects into two sequences, weaker than $\mathrm{B}>11^{\mathrm{m}}$ (FWHM $<30$ pixels) and a brighter $\mathrm{B}<11^{\mathrm{m}}$. Bright objects need additional filtration (smoothing) procedures to prevent the generation of false objects. Dividing objects into two sequences will need about $50 \%$ more processing time.

\section{References}

Andruk V.M., Pakuliak L.K., Golovnia V.V. et al.: 2015, Odessa Astron. Publ., 28, 192.

Andruk V.M., Golovnia V.V., Ivanov G.A. et al.: 2016, Kinem. Phys. Cel. Bodies, 32, N1, 32.

Andruk V., Yuldoshev Q., Eglitis I. et al.: 2017, Odessa Astron. Publ., 30, 159.

Andruk V.M., Pakuliak L.K., Golovnia V.V. et al.: 2017, Science and Innovation, 13, N1, 17.

Andruk V., Eglitis I., Protsyuk Yu. et al.: 2019, Odessa Astron. Publ., 32, in press.

Gaia Collaboration 2018, A\&A, 616, A1.

Hambly N.C. et al.: 2001a, MNRAS, 326, 1279.

Hambly N.C., Irwin M.J., MacGillivray H.T.: 2001b, MNRAS, 326, 1295.

Hog E. et al.: 2000, A\&A, 355, L27.

Pakuliak L.K., Andruk V.M., Golovnia V.V. et al.: 2016, Odessa Astron. Publ., 29, 132.

Protsyuk Yu.I., Kovylianska O.E., Protsyuk S.V. et al.: 2014, Odessa Astron. Publ., 27, 63.

Relke E., Protsyuk Yu.I., Andruk V.M.: 2015, Odessa Astron. Publ., 28, 211. 